\title{
Human Motivational Behavior: From West and Islamic Perspective
}

\author{
Mariam Abd Majid ${ }^{1}$ \\ Syarul Azman Shaharuddin ${ }^{1}$ \\ Abur Hamdi Usman ${ }^{1}$ \\ Fakhri Sungit ${ }^{1}$ \\ ${ }^{1}$ Faculty of Islamic Civilization Studies, International Islamic University College Selangor (KUIS), Malaysia \\ Corresponding Author Email: aburhamdi@kuis.edu.my
}

\section{Doi:10.5901/mjss.2016.v7n3s1p106}

\section{Abstract}

This article discusses on human motivational behavior from the perspective of western and Islam. According to some Western psychologists, the aspects of physiology, biology, psychosocial, biosociopsychology are among the factors that drive the behavior of human, while according to Islam, the needs of body and soul as basic of human creation have implications for human behavior. By adopting documentation method and comparative analysis, this article found that human behavior motivated by the needs of the body and the spirit, which comprises elements of al-nafs (soul), al-qalb (heart), al-bashirah (the mind's eye view), and common sense proposition that was proven through naqli. There are similarities and differences of West and Islamic view related to psychological impulses of human behavior.

Keywords: Human; Behavior; Motivation; Western; Islam; Psychology

\section{Introduction}

The drive human behavior is the focus in psychological discipline (Stern, 2000). Psychology defined as a discipline of study that examines the thoughts, lives and human behavior (Mahmood, 1992). The study of psychology explains that the behavior of an individual human being is influenced by two main domains: thought and spirit. The biological, psychosocial and bio psychosocial factors give a strong influence on an individual behavior (Ahmad, 1999).

The objective of this paper is to present aspects of human motivational behavior according to the dictates of the Western world and Islam. The results outcome should provide an important fact in order to understand in depth of human behavior. And finally, to propose various plans and programs in the society in general. There are several contributions from this paper, such as; it contributes to the scholarly writing, to increase of exploration in understanding the human behavior, and to organize more new dynamic and strategic activities for the goodness of society and environment.

\section{Motivation of Human Behavior}

Human behavior did not occur by chance but it was moved, driven or motivated by internal factors and external of the soul (Ainslie, 2001). There are different views in relation to the encouragement of human behavior. The motivation of human behavior is mostly influenced by the brilliant internal factors, such as spiritual and religious aspects, as well as external factors, such as environment and effective communication (Razak, 2006). High motivation on working environment or organizational culture contributes a high impact to increase the behavior of an employee in an organization (Brahmasari \& Suprayetno, 2009). There are previous studies conducted which found that the goals of job satisfaction can drive employee motivation in order to involve itself actively in work and to be excellent workers and demonstrate a high commitment to the organization continuesly (Adey \& Bahari, 2010; Chiesa, 1994).

Motivation influences the behavior of an individual human being whether they exist, remain or be ignored. It also seeks to encourage behavioral choices that must be made by one man (Weiner, 1992). Motivation derived from the Latin word movere namely to move. Council Dictionary defines motivation as the harsh desire or strong spirit in a person that drives him to try to do something and aiming for success (Anon, 1991). Motivation defined as the internal state of conducting motion and give direction to the thoughts, feelings and behavior. This situation drives and controls the 
behavior towards the attainment of a goal (Redzuan \& Abdullah, 2002). Motivation can be understood as a joint action or conduct of a movement oriented to a goal (Elliot \& Sheldon, 1997).

There are various theories could explain the relationship between motivation and the factors that drive the actions (Baum, 2005). The process begins with the birth of motivation or desire within an individual. Desires and needs that exist in a person will motivate for an action to meet those needs. The feeling of satisfaction appears in person when requirements can be met (Huffman, 2005). Needs that exist can determine the goal that an individual wants to achieve. A firm motivation of an individual will deploy a behavior to achieve the goal desired (Husain, 1996). Figure 1 illustrates the motivation process that drives a human behavior.

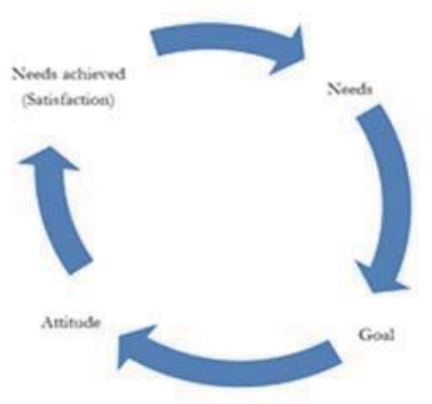

Figure 1. Circle of Motivation

Source: Karen Huffman, Mark Vernoy \& Judith Vernoy (1994)

The achievement of a goal targeted by human is a starting point on cycle of motivation as well as it is being able to put the individual in the sense of complacency. Conversely, if a specified target cannot be reached, the person will continue to strive to act so as to achieve the goals and objectives that was targeted. Desire and goal that exist will set a behavior to human (Gollowitzer, 1996).

\section{Desires and Goal in Human's Motivational Behavior}

Psychologists argued that the motive of an individual is a goal to be achieved (Skinner, 1935). The objective is realized through a sets of measures that disclosed by the behavior of an individual human being. Normally, one would have fully committed the pursuit of a goal which give meaning to him (Carver \& Scheier, 2003). Psychologists explained among goals that provide motivation for the actions or behavior of an individual human being as follows (Dweck, 1991);

\subsection{Motivation to Fulfill the Biological Urges}

Human will always strive to meet their biological needs (Mahmood, 1992). Among the reasons to fulfill and individual biological needs is to fulfill the intuition requirements and to maintain the self stability:

\subsubsection{Fulfilling the intuition requirement}

Motivation theory on intuition suggests that a human will do something to meet the needs or demands of his intuition. Energy intuition is in the impetus for action in human. Someone's intuition is something that is not learned but acquired through disposition or natural cause. Motivation which meet the requirements of this intuition is described as a mother who tries to get medicine to cure diseases suffered by children who is sick. Action to find a drug to treat a disease experienced by children was naturally driven by love of his mother. Mother will feel satisfied when her seeks to obtain medicine that could cure her child's illness is reached, yet she will continue to seek other remedies if the goal of curing the child illness has not been successful (Redzuan \& Abdullah, 2002). In other words, human will act based on their instinct. 


\subsubsection{Self-sustaining stability}

Maintaining the stability among the goals that drive someone's behavior. Human try to eliminate the impulses that exist upon themselves. This impulse will emerge when they found a deficiency within themselves. This impulse elimination process focused on the mechanisms of internal motivation. Encourage reduction motivation theory explains that any human being has the motivation to reduce the inner impulse of what they have (Mahmood, 1992).

The urge that exist will be reduced when the need is fulfilled (Redzuan \& Abdullah, 2002). Someone will try to fulfill his hunger for food. The drive to get food will increase as long as the food is sought has not been obtained to reduce the hunger impulse. A sense of satisfaction will be experienced when food is available and the hunger that suffers has been satisfied (Desmet \& Schifferstein, 2008). It means the drive to achieve the goals of maintaining the self stability has been reduced because of the requirement to eat is fulfilled. Satisfied feeling is achieved when any shortcomings is fulfilled. Human is compelled to fulfill the biological needs, which are biological instincts and maintain their stability. Human behavior or actions motivated by both the biological needs.

\subsection{Fulfilling the Psychosocial Needs}

Human has always sought to achieve psychosocial needs, such as receiving an award and a gift (Brunstein \& Maier, 2005). Among the psychosocial needs of the human person are:

\subsubsection{Acquiring incentives}

Incentives are an external stimulus that motivate someone's behavior. When someone is full, the motivation to get food is reaching to the lowest level. But the existence of a meal that looks delicious are still working to stimulate his desire to eat. Thus, according to the theory of incentives in motivation, stimulation, and external factors can lead a person's behaviour (Mahmood, 1992).

There are several incentives criteria that can stimulate someone. The needful incentive is more acceptable than incentives are not necessary and positive incentives more approachable than the negative. Someone who does not have a friend to sit and enjoy a meal on the event he attend, but a person who has many friends will use the opportunity to chat with old friends regardless of the dishes served as chatting with some old friends is more important to him at that time. Thus, the selection is done by a man by the pull of the current incentives and requirements available at the time. At the same time, a matter or event that has ever hurt someone in the past is a definite negative incentives shunned by someone (Redzuan \& Abdullah, 2002).

Reinforcement of motivation theory explains that most of human behavior can be shaped through positive or negative reinforcement. Motivation is not only subjected to the factors, such as intention to conduct something good and effective, but it also involves some factors such as confirmation. For example, an award for something good and productive undertaken. Reward is a one form of incentive for the implementation of behavior. If someone is satisfied for receiving a reward after an honest and perfect actions he undertook, then typically it will become a motivation to do it again to get the reward.

\subsubsection{To reach the self fulfillment}

Cognitive theory of motivation splits between intrinsic and extrinsic motivation. Intrinsic motivation prompts a man to do an activity to achieve inner satisfaction from the results of the implementation of the activity, while extrinsic motivation motivate a man to do something to achieve an outside satisfaction from these activities such as a reward. The studies conducted found a man will work harder, diligently, more conscientious and will produce good quality when the task is motivated more by intrinsic than extrinsic motivation (Desa, 2002). Someone who is driven to implement an action due to intrinsic motivation will be able to feel the inner satisfaction after completing or experience the satisfaction from the result of his action (McCullough Chavis, 2011).

\subsubsection{Achieving the targeted goals}

A man is driven to execute an action when assuming his target is actually can be achieved. This phenomenon is explained in the theory of achievement motivation by David Clarence McClelland (1917-1998) was an American psychologist, noted for his work on Need Theory. Based on this theory, a man motivated to do something if they feel 
some goal can be achieved. Conversely, he won't do it if the targeted goals are presumably can't be achieved. A person will feel satisfaction when the targeted goals are achieved (McClelland, et al, 1976; Harackiewicz, et al,1997).

A feeling of satisfaction is reached when someone is reaching the targeted goals or when the reality meets the expectation. Victor Vroom on his expectancy theory states that someone's behavior is a reflection from decision he took (Hassan, 2001). So according to this theory, a man of hope and predictions about what will happen in the future. Normally, all decisions made by a person are based on what is expected and predicted to occur for the decision taken. When a completed act gave a lot of kindness, a sense of satisfaction will increase, conversely for an opposite situation; the human sense of dissatisfaction will increase. Someone's act for its incentive inducement, inner satisfaction and the confident of reaching the targeted goals (Thompson, Davidson, \& Barber, 1995).

\subsubsection{Environment}

Environmental factors as among other factors that helped driving human behavior. Objects that surround a person like the ecology, architecture, the situation of psychosocial, and social factors such as position in the community, education levels and political affiliation are elements of environment that also contributed to the behavior of an individual human being (Ahmad, 1999). Environment will also encourage actions and behavior of a human to adapt according to its surrounding (Thyer, Dulmus, \& Sowers, 2012).

\subsection{To Achieve the Bio-psychosocial Goal}

The goal of the bio-psychosocial is of one a theory of motivation that combines two requirements, namely the goal of biological and psychosocial objectives. Abraham Maslow's theory explains the goal of the bio-psychosocial of a human as illustrated in figure 2.

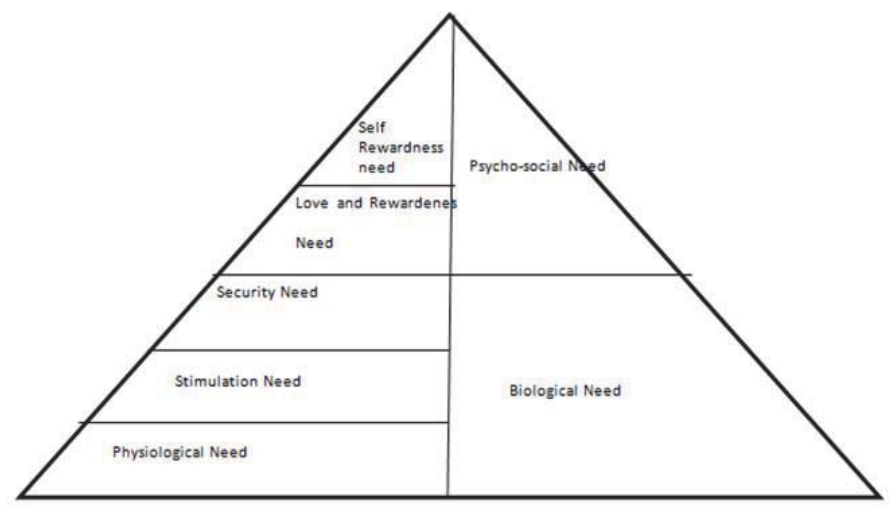

Figure 2. Abraham Maslow's theory

This theory highlights the need for human motif arranged in a pyramid shape and form a hierarchy qualification. Abraham Harold Maslow (1908-1970) was an American psychologist who was best known for creating Maslow's hierarchy of needs, a theory of psychological health predicated on fulfilling innate human needs in priority, culminating in selfactualization. Maslow said that man must meet every requirement in each level of the hierarchy (Oleson, 2004; Dye, Mills \& Weatherbee, 2005; Minshull, Ross \& Turner, 1986).

Desire starts at the lowest level as a physiological need such as food, water, air, shelter, clothing and other needs as most basic needs. Than the human needs move to the second stage of stimulant need. Third stage is the needs for assurance and security, this stage is where human needs to fulfill their prosperity such as having a job and a house. The fourth is the needs of love and self belonging. At this stage people will meet the needs of love and compassion. The fifth stage is the need of self-esteem that people will be motivated to fulfill this requirement to seek life satisfaction also in work to be respected as useful person and being contributed to the society. And finally is the need for the self perfection. On this fifth hierarchy Maslow suggested that human needs are driven by the desire to achieve something in their life and to reach self perfection. The struggle to fulfill something more meaningful in life is a one strong motivation (Sanford, 
1961).

According to Maslow, people will try to meet the five self requirements physiological needs, safety, social, esteem and love and self-realization. A failure to fulfill those needs can cause a person to feel uncomfortable and so they will keep trying to achieve it. The top of the human needs is self-realization or to become something it desired. If a person fails to comply with this requirement he will suffer otherwise when someone is able to meet these requirements, he will feel his life meaningful and feel satisfied (Strand, Coyne \& Silvia, 2008). According to Maslow, there are two motives that drive human to seek the meaning of life, namely the deficiency motive and the motive for growth (Cohen \& Cairns, 2012). Deficiency motive of human is an impulse to seek something that is needed to get something that does not exist within itself (Pyszczynski, Greenberg, \& Solomon, 1997). A sad and solitary person needs someone for a company and getting rid of his loneliness. The concept is similar to the situation of a person who lacks food or drink will strive to reduce the requirement. Growth motive is the urge to get something useful and meaningful and not based on needs. One would have to study hard, driven by a sense to acquire knowledge to help community members in need. Assisting members of the society who are in need will produce the feeling of satisfaction for services rendered subsequently contribute to the experience of life with more meaningful. Someone who wants to reach perfection will do something that has meaning in life and this will satisfy their heart and soul (Desa, 2002). Maslow's theory suggests the complexity of human needs and stressed out that when basic biological needs have not been met relatively human will not seek to fulfill the other needs yet.

\subsection{Religiosity Need}

Religion is the main focus as the needs and goals of the behavior of an individual (Dennett, 2006). Religion is also a guide to determine the actions taken by someone. Aspects of faith in Allah, the existence of the Judgment day, belief in fate and the provision of Allah and supernatural things are the main catalyst for the movement and behavior of an individual human being (Ahmad, 1999). Individuals who have religious beliefs will have guidance and define the scope and limits of human behavior and actions (Clark, \& Winslett, 2011). Man was created from the fusion of the two elements that complement the body and soul perfection event. The Qur'an describes human creation is related to the word of Allah in sura al-Hijr verse 28:

"Verily, I (Allah) to create man of dried clay came from mud molded into shape. So, when I have created him and have breathed into him a soul (created) and have those (angels) bowed to him."

Humans have psychological needs that are very important in life to elevate the spiritual needs of the soul and spirit (al-Najati, 2005). It means human bounded by body and soul needs to be met and also it proves that the people affected by the need to meet the physical needs and demands and the spirit that exists in every individual. Therefore, a body and soul element give a strong influence on the human and has influence in organizing the all form of life (Beck, 2002).

The aspect of soul or nafs is a dominant aspect of the people. Allah says in Sura al-Shams, verse 9 which means:

"Truly success for those that purifies the soul and losers who pollute his soul."

Sacred being is capable of forming a good heart (al-qalb). From a physical aspect, al-qalb is a blood clot which is located on the left side of the chest. It serves to control the entire circulation of blood and become a source of life. From a view of spiritually it is smooth, soft and determine the nature of man. Al-Qalb has a natural positive characteristic of tending to do well. All human behavior is driven by al-qalb desire (Lebar, 1994). Al-Qalb certainly produce good people who have good behavior, as the Prophet said which reported by al-Bukhari and Muslim:

"Know that the body is mudghah (lump of flesh), if it is good, then the better the whole body. If it is damaged, then the whole body is also damaged. Know that a piece of meat that is heart"

Element of spirit in human is established by Allah and among the highest gift of Him. The next spiritual element is al-aql (common sense). al-Aql is the main thing that was made by Allah. al-Aql defines as an understanding of human to reason about something. Function of al-aql is to find and communicate science to the heart and thus approaching Allah (Ramadan, 2013), and physically it was called brain. al-Aql is capable to radiate the spirit, can understand the invisible things and try to understand an abstract object (Lebar, 1994).

Based on the above description, the soul is an element which greatly affects the behavior of an individual approach. Among method of approaches is to ensure the deeds that will please the soul such as good statement, good 
service, and pure feeling towards human. In addition to the aspects of thought and soul, the human is also concerned about the physical needs of society. Physical needs of human are associated with physiological activities in the body as a substance element. And it will invite humans to need their food and drink for the body in balance. People will feel hungry, thirsty, need to air, rest, sleep, and will avoid pain and so on (al-Najati, 2005). Meanwhile, the rising cost of living, poverty, the more serious the disease facing humanity in the world today is one of the challenges to human well also have implications for the conduct of a human. The issue of a Muslim that received aid from church has shocked all Muslims earlier. This proves that aspects of physical needs is the one we should look at and be given more attention especially today (Schoenfeld, 1993).

Based on the findings above, it is concluded that the aspects of the mind, the soul and the physical affects the whole aspects of human life. Therefore, the strategy of approaching the society must have the influence and the needs of thinking aspects, physical, and soul toward humans.

There are some noteworthy that can be implemented in the formulation of plans and programs towards positive behaviors. It can be implemented by supplying the thought of society according to the teaching in accordance with Quran and Hadith (prophetic tradition) teachings. Human thought which based on the right knowledge will affect to the society to justify the right action in line with the doctrine held. Forms of distorted attack on the on the teaching of religion such as pluralism, liberalism, feminism and some other school of thought is one of the serious threats to the community as well as a challenge to the clergy. Schools of thought have affected the thoughts and society actions. Some heresies that appeared on this day is one form of attack that can damage the thought of the people. Serious efforts should be made to provide people with the right mentality sources to ensure people perform the correct action. And according to Islam, human behavior is influenced by the spiritual aspect of the covering of the soul or al-nafs, al-qalb and al-ruh (spirit).

\section{Conclusion}

There are two elements that affect to the human behavior, namely the thought element and the element of soul. The efforts should be formulated based on the concentration of these elements that influence of human behavior. In Islam, the religious factors could affect the behavior of an individual human being. Religion affects the physical and spiritual elements became the two major domain of an individual who attempt to break the hearts of men than it stimulate the society to perform changes based on the da'wah which they received.

Thus, among the main aspects that serve to motivate action and behavior of an individual human being are; religion, the aspect of needs and biological, psychosocial needs, bio psychosocial needs and goals of the blending of biological and psychosocial needs of the human. The process should emphasize motivational impetus for creating a sense of purpose in the soul. The existences of needs on people tend to show human into one targeted objective. The implementation process needs to point of motivate the right and appropriate goals of human being. Right and appropriate goals will produce the correct action and far from falsehood or error. A process motivation was to be followed by the process of guiding the behavior of an individual human being through the actions to ensure appropriate action would betaken. Implementation of this guidance can be beneficial when the challenges and problems faced by a person identified as challenges and obstacles because they are a major obstacle in ensuring the achievement of the goals set. The goal of motivation process was to ensure that one could commit their motivation to its behavior so that one can sense satisfaction of high relief situation in the soul which eventually realizes the nature and steadfast commitment to positive behaviors that are expected.

\section{References}

Adey, N. H., \& Bahari, F. H. (2010). Hubungan antara kecerdasan emosi, kepuasan kerja dan komitmen terhadap organisasi [The relationship between emotional intelligence, job satisfaction and organizational commitment]. Jurnal Kemanusiaan, 16.

Ahmad Mubarok. (1999). Psikologi Dakwah [The Psychology of Dakwah]. Jakarta: Bina Ilmu.

Ainslie, G. (2001). Breakdown of will. New York: Cambridge University Press.

Al-Najati, M. U. (2005). Qur'an and Psychology. Bandung: Pustaka Hidayah.

Anon. (1991). Kamus Dewan. Kuala Lumpur: Dewan Bahasa dan Pustaka.

Baum, W. M. (2005). Understanding behaviorism: Behavior, culture, and evolution. Oxford, England: Blackwell.

Beck, J. R. (2002). Self and soul: Exploring the boundary between psychotherapy and spiritual formation. Journal of Psychology and Theology, 31(1), 24-36.

Brahmasari, I. A., \& Suprayetno, A. (2009). Pengaruh Motivasi Kerja, Kepemimpinan dan Budaya Organisasi Terhadap Kepuasan Kerja Karyawan serta Dampaknya pada Kinerja Perusahaan (Studi kasus pada PT. Pei Hai International Wiratama Indonesia) [The Influence of Work Motivation, Leadership and Organizational Culture on Employee Satisfaction and its Impact on Corporate 
Performance (A Case Study at PT. Pei Hai International Wiratama Indonesia]. Jurnal Manajemen dan Kewirausahaan (Journal of Management and Entrepreneurship), 10(2), pp-124.

Brunstein, J. C., \& Maier, G. W. (2005). Implicit and self-attributed motives to achieve: Two separate but interacting needs. Journal of Personality and Social Psychology, 89, 205-222.

Carver, C. S., \& Scheier, M. F. (2003). Three human strengths. A psychology of human strengths: Fundamental questions and future directions for a positive psychology, 87-102.

Chiesa, M. (1994). Radical behaviorism: The philosophy and the science. Sarasota, FL: Authors Cooperative.

Clark, K. J., \& Winslett, J. T. (2011). The evolutionary psychology of Chinese religion: Pre-Qin high Gods as punishers and rewarders. Journal of the American Academy of Religion, 79(4), 928-960.

Cohen, K., \& Cairns, D. (2012). Is searching for meaning in life associated with reduced subjective well-being? Confirmation and possible moderators. Journal of Happiness Studies, 13(2), 313-331.

Dennett, D. C. (2006). Breaking the spell: Religion as a natural phenomenon. New York: Penguin.

Desa, A. (2002). Psikologi untuk golongan profesional [Psychology for Professionals]. Malaysia: McGraw Hill.

Desmet, P. M., \& Schifferstein, H. N. (2008). Sources of positive and negative emotions in food experience. Appetite, 50(2), $290-301$.

Dweck, C. S. (1991). Self-theories and goals: Their role in motivation, personality, and development. In Nebraska symposium on motivation (Vol. 38, No. 3, pp. 199-235). Lincoln, NE: University of Nebraska Press.

Dye, K., Mills, A. J., \& Weatherbee, T. (2005). Maslow: man interrupted: reading management theory in context. Management Decision, 43(10), 1375-1395.

Elliot, A. J., \& Sheldon, K. M. (1997). Avoidance achievement motivation: A personal goals analysis. Journal of Personality and Social Psychology, 73, 171-185.

Gollowitzer, P. (1996). The psychology of action: Linking cognition and motivation to behavior. New York: Guilford.

Harackiewicz, J. M., Barron, K. E., Carter, S. M., Lehto, A. T., \& Elliot, A. J. (1997). Predictors and consequences of achievement goals in the college classroom: Maintaining interest and making the grade. Journal of Personality and Social Psychology, 73, 12841295.

Hassan, Abdullah. (2001). Psikologi Moden Untuk Bakal Pendakwah [Modern psychology For Coming Preacher]. Kuala Lumpur: PTS Publication.

Huffman, K. (2005). Living psychology. USA: John Wiley \& Sons.

Husain, M. G. (1996). Psychology and Society in Islamic Perspective. Institute of Objective Studies.

Lebar, M. S. (1994). Asas Psikologi: Perkembangan Pengajian dan Pendidikan [Basic of Psychology: Development Learning and Education]. Kuala Lumpur: Utusan Publications \& Distributors.

Mahmood Nazar Mohamed. (1992). Pengantar Psikologi [Introduction to Psychology]. Kuala Lumpur: Pustaka Fajar.

McClelland, D. C., Atkinson, J. W., Clark, R. A., \& Lowell, E. L. (1976). The achievement motive. USA: Appleton Century Crofts, Inc.

McCullough Chavis, A. (2011). Social learning theory and behavioral therapy: Considering human behaviors within the social and cultural context of individuals and families. Social work in public health, 26(5), 471-481.

Minshull, J., Ross, K., \& Turner, J. (1986). The human needs model of nursing. Journal of Advanced Nursing, 11(6), 643-649.

Oleson, M. (2004). Exploring the relationship between money attitudes and Maslow's hierarchy of needs. International Journal of Consumer Studies, 28(1), 83-92.

Pyszczynski, T., Greenberg, J., \& Solomon, S. (1997). Why do we need what we need? A terror management perspective on the roots of human social motivation. Psychological Inquiry, 8(1), 1-20.

Ramadan, T. (2013). The challenges and future of applied Islamic ethics discourse: a radical reform?. Theoretical medicine and bioethics, 34 (2), 105-115.

Razak, A. Z. A. (2006). Ciri iklim sekolah berkesan: Implikasinya terhadap motivasi pembelajaran [The Characteristics of effective school climate: Its implication towards learning motivation]. Jurnal Pendidikan Malaysia, 31, 3-19.

Redzuan, M. \& Abdullah, H. (2002). Psikologi [Psychology]. Malaysia: McGraw Hill Sdn. Bhd.

Redzuan, M. (2001). Psikologi Sosial [The Social Psychology]. Serdang: Universiti Putra Malaysia.

Sanford, F. H. (1961). Instructor's manual for Psychology: A scientific study of man. USA: Wadsworth Publishing Company.

Schoenfeld, W. N. (1993). Religion and human behavior. Boston: Authors Cooperative.

Skinner, B. F. (1935). The generic nature of the concepts of stimulus and response. Journal of General Psychology, 12, 40-65.

Stern, P. C. (2000). Psychology and the science of human-environment interactions. American psychologist, 55(5), 523.

Strand, P. S., Coyne, L. W., \& Silvia, K. (2008). Behavioral conceptualization. In M. Hersen \& D. Reitman (Eds.). Handbook of psychological assessment, case conceptualization, and treatment, Vol. 2. Children and adolescents (pp. 53-75). Hoboken, NJ: Wiley.

Thompson, T., Davidson, J. A., \& Barber, J. G. (1995), Self-worth protection in achievement motivation: Performance effects and atributional behavior. Journal of Educational Psychology, 87, 598-610.

Thyer, B. A., Dulmus, C. N., \& Sowers, K. M. (2012). Human behavior in the social environment: Theories for social work practice. USA: John Wiley \& Sons.

Weiner, B. (1992). Human motivation: Metaphors, theories, and research. USA: Sage. 